\title{
The Application of Blockchain Technology in Crowdfunding: Towards Financial Inclusion via Technology
}

\author{
Aishath Muneeza, \\ Nur Aishah Arshad, \\ Asma' Tajul Arifin \\ International Centre for Education in Islamic Finance (INCEIF) \\ Malaysia
}

\begin{abstract}
The emergence of innovative digital financial technologies, namely blockchain and crowdfunding, indicates new ways to reach the poor and economically vulnerable groups. This paper contributes to the emerging literature on financial technology by presenting the case of crowdfunding in financial inclusion. The rationale behind this inquiry is to demonstrate the relevance of crowdfunding to financial inclusion, and how might blockchain technology fuel the development of crowdfunding. This paper also constitutes one of the first attempts to analyse crowdfunding in Malaysia and Shariah-compliant crowdfunding. In this paper, a desk research is conducted where journal articles, books, magazines, newspapers, industry reports published on the subject matter are reviewed critically. To analyse the development of crowdfunding in Malaysia, 6 crowdfunding platforms are examined. The outcome of this research suggests that crowdfunding is a viable means to promote financial inclusion, and blockchain technology could help mitigate the current issues faced by platform operators.
\end{abstract}

Keywords: Blockchain Technology; Crowdfunding; Financial Inclusion; Islamic Finance and Banking; Islamic Crowdfunding 


\section{Introduction}

Financial inclusion has become a prominent financial reform agenda in most countries around the world. This phenomenon stems from the realisation that an inclusive financial system is critical in reducing poverty and promoting shared prosperity. In reference to The World Bank (2018), "financial inclusion means that individuals and businesses have access to useful and affordable financial products and services that meet their needs such as transactions, payments, savings, credit and insurance, and being delivered in a responsible and sustainable way". Kim and De Moor (2017) highlighted that financial exclusion is not limited to individuals but also extends to companies, especially for small and medium enterprises (SMEs) which have limited or no financial supports.

The rise of digital financial services indicates an alternative to reach the financially excluded people with a range of financial services in a cost-effective and sustainable manner. Financial innovations such as microfinance, mobile payment, crowdfunding, and cryptography are playing a vital role in providing greater financial access to the financially underserved populations. In particular, the growing use of crowdfunding platforms and blockchain has created new means to reach financially constrained individuals, households and companies.

It is in this regard that this study analyses the role of crowdfunding and blockchain in expanding financial inclusion based on data from Malaysia. Although there is growing literatures examine crowdfunding, little work is done in the context of Muslim developing countries and financial inclusion. According to a report by Pew Research Center (2011), Muslim-majority countries are among the poorest in the world, as measured by gross domestic product (GDP) per capita in U.S. dollars. Moreover, the number of venture capitalists in the Arab world is alarmingly insufficient, compared to the rising demand for venture capital (Taha and Macias, 2014). The main purpose of this paper is thus to explore crowdfunding as a means to widen financial access in Muslim developing country, and Malaysia was chosen for a number of reasons. First, Malaysia has achieved one of the highest levels of financial inclusion among Southeast Asia countries, due in part to policies taking advantage of digital technology to expand financial access for all (World Bank, 2017). The Global Findex Database of the World Bank revealed that 81 percent of Malaysia's adults had an account at a licensed financial institution in 2014 which indicate high levels of financial inclusion (Demirgüç-Kunt et al., 2018; World Bank, 2017). Second, Malaysia is one of the first countries in Southeast Asia to give regulatory approval for equity crowdfunding, and the number of crowdfunding platforms in Malaysia is rising (Thas Thaker et al., 2018).

\section{Methodology}

This is a desk research where literatures written on the subject are reviewed to derive conclusions. As such, data required for the study is primarily collected from secondary sources consist of books, research articles, industry reports, various websites, trade journals, magazines, and newspapers.

International Journal of Management and Applied Research, 2018, Vol. 5, No. 2 


\section{Literature Review}

\subsection{Financial Inclusion and Crowdfunding}

Financial inclusion has become a global agenda in order to bridge the gap between the poor and the rich. The World Bank has been keeping track on global financial inclusion to ensure that all planned agenda in upholding it are implemented accordingly. The Global Financial Inclusion Database (Global Findex) covers more than 140 economies, and the indicators of financial inclusion measure how people save, borrow, make payments and manage risk. According to the 2017 Global Findex survey, 69 percent of adults or 3.8 billion people as of 2017 have a bank account (Demirguiç-Kunt et al., 2018). There are reasons why globally 31 percent of the adults are unbanked. The most commonly cited barrier include: lack of enough money, they believe they do not need an account, accounts are too expensive, family members already have an account, financial institutions too far way, lack of necessary documentation, lack of trust, and religious reasons (Demirgüç-Kunt et al., 2018). An examination at these reasons reveals that limited access to finance (lack of money, banks are too far away) is the main battier to create a bank account, while personal belief (religious reasons, felt unnecessary to open account) comprises a small part.

Studies show that there has been a significant increase in the use of mobile phones and the internet to conduct financial transactions (Demirgüç-Kunt et al., 2018; Ouma et al., 2017; World Bank, 2013). Between 2014 and 2017, this has contributed to a rise in the share of account owners sending or receiving payments digitally from 67 percent to 76 percent globally, and in the developing world from 57 percent to 70 percent (Demirgüç-Kunt et al., 2018). The growing internet access through affordable devices could enable those from developing countries to use a cheaper payment system in making money transactions. According to the data by the World Bank, globally there are 1.7 billion adults remain unbanked, yet two-thirds of them own a mobile phone that enables them to access financial services (see Figure 1).

Figure 1: Unbanked adults who own a mobile phone Two-thirds of unbanked adults have a mobile phone Adults without an account owning a mobile phone, 2017

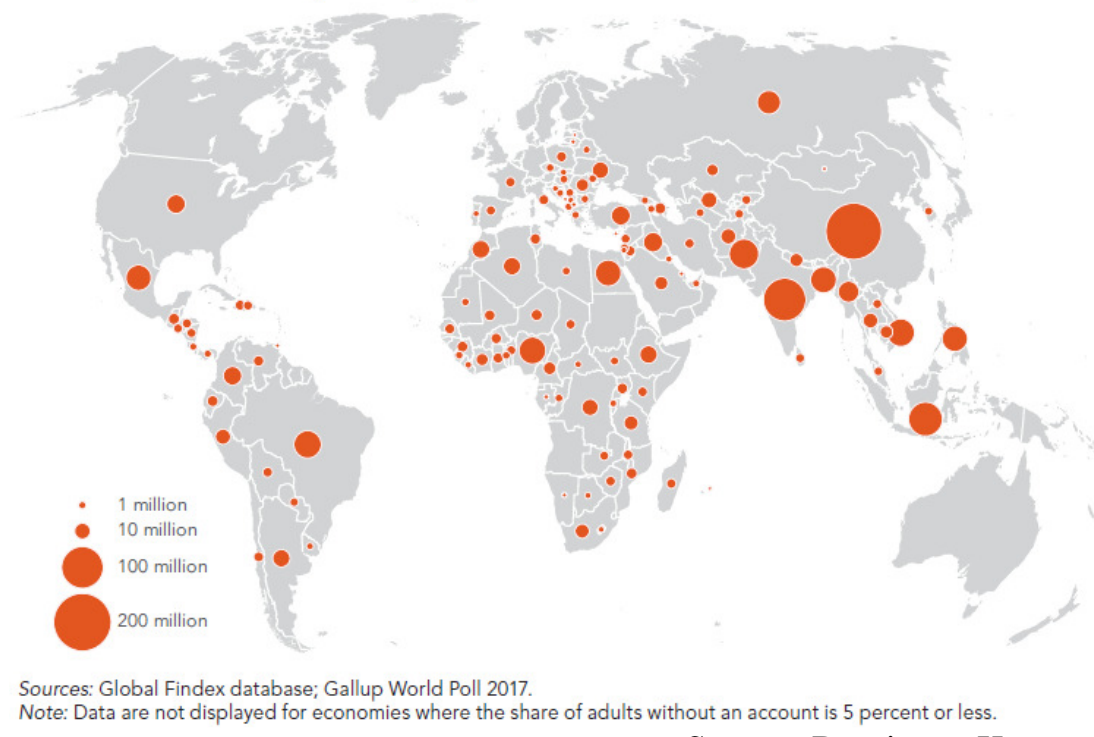

Source: Demirgüç-Kunt et al. (2018: 11)

International Journal of Management and Applied Research, 2018, Vol. 5, No. 2 
Jenik et al. (2017) suggest that crowdfunding can benefit financial inclusion efforts is grounded in the following ways: $(i)$ it improves access to finance by excluded and underserved individuals and micro, small, and medium enterprises; (ii) it allows for innovations of existing models to serve Bottom of Pyramid (BoP) customers, such as microfinance and mobile financial services; and (iii) it opens access to more complex investment products for resilience and asset building. A study by World Bank (2013) indicates that there is an opportunity for up to 344 million people in developing economies to participate in crowdfunding. Crowdfunding also opens access to funding and investment opportunities that are currently unavailable to customers at the BoP. To ensure that people benefit from digital financial services, it is important to have a well developed payments system, good physical infrastructure, appropriate regulations, and vigorous consumer protection safeguards (Demirgüç-Kunt et al., 2018).

At the core of crowdfunding are two defining aspects: first, raising small amounts of money from a large number of people (hence the term 'crowd'); second, the fundraising and transactions take place via the internet. The World Bank (2013) defines crowdfunding as an internet-enabled way for businesses or other organizations to raise money in the form of either donations or investments from multiple individuals. Similarly, Kirby and Worner (2014) described crowdfunding occurs where small amounts of money is obtained from a large number of individuals or organisations, to fund a project, a business or personal loan, and other needs through an online web-based platform in crowdfunding. In short, crowdfunding can be described as an internet enabled platform that is open for individuals or corporations for particular purposes, including wealth creation and social value creation.

United States (US) began to implement crowdfunding in 2007 and was subsequently followed by other markets in later after the 2008 global financial crisis (Jenik et al, 2017; Kirby and Worner, 2014; Kim and De Moor, 2017). Crowdfunding offers an alternative to traditional banking, which has grown rapidly in markets driven by technology, as well as macroeconomic and regulatory factors (Jenik et al, 2017). Crowrdfunding can be categorised into four: loan, equity, reward, and donation. While the former two involves financial returns, the latter two have no payback.

With the growing emphasis on the social roles of financial services, crowdfunding could be seen as an innovative way to improve financial inclusion (Jenik et al, 2017; Kim and De Moor, 2017). Many developing countries are on the verge of financial exclusion due to remoteness, restricted access to financial services, lack of money, and lack of necessary documentation, which indicates the weakness in the existing financial system (Demirgüç-Kunt et al., 2018). Financial technology in a broader sense can increase financial inclusion because it has a capability to reach the financially vulnerable populations. For instance, mobile banking and electronic financial transactions are considered important ways to promote financial inclusion due to its accessibility, affordability, and safety (Ouma et al., 2017). Equally, crowdfunding can help those who have limited access to finance to raise funds quickly at affordable cost. Nonetheless, crowdfunding still can be further enhanced by altering a certain set of regulations in order to improve its implementation (Kim and De Moor, 2017).

International Journal of Management and Applied Research, 2018, Vol. 5, No. 2 
Blockchain-based financial services could help to resolve the dependency of the unbanked on cash and traditional peer-to-peer trust circles. Theoretically, blockchain technology is a solution that allows an efficient and low-cost equity registration, equity transaction and transfer, and shareholder voting in the crowdfunding industry, and eliminating legal risks related to fund management (Zhu and Zhou, 2016). However, there are many legal and technical issues to be resolved for bloackchain technology to be widely implemented in the market (Guo and Liang, 2016; Zhu and Zhou, 2016).

\subsection{Overview of Islamic Crowdfunding}

The concept of crowdfunding is in line with Islamic teachings in which Allah said in the Quran, "Cooperate in righteousness and piety". To a great extent, crowdfunding and Islamic finance have many similarities. Both Islamic finance and crowdfunding place a strong emphasis on trust and most importantly, both share the same principle of financing: profit and loss sharing philosophy (Asian Institute of Finance, 2017; Taha and Macias, 2014: 116).

Crowdfunding can be conceptualised as "Shariah compliance" if it conforms to Shariah law: share profit and loss, does not involve in prohibited industries (alcohol, pork, drug, etc), and does not charge any interest on lending. While most crowdfunding categories fit into these principles of Islamic finance, loan-based crowdfunding requires adaptation to be Shariah compliant (IFSB, 2017; Marzban and Asutay, 2014; Taha and Macias, 2014). More specifically, equity-based crowdfunding can be equated with the PLS concept of Islamic finance, while donation-based crowdfunding matches the mandatory charitable contribution in Islam -- zakah. While reward-based crowdfunding has no parallels in Islamic finance, it does not challenge its principles because money is exchanged for non-financial rewards. However, loanbased crowdfunding would need to be interest-free in order to comply with Shariah law. Any excess amount taken when repaying is considered Riba which is not permissible in Islam.

The Islamic Financial Services Board (IFSB) recognised the importance of crowdfunding, as can be shown in the efforts of Organisation of Islamic Cooperation (OIC) to introduce Shariah compliant crowdfunding platforms to the local funding ecosystem. In its annual Islamic financial services industry stability report, IFSB (2017) reported that there are 80 active crowdfunding platforms with a primary location in an OIC member state. However, most of these platforms do not provide the full details of admission criteria, contracts, as well as measures to ensure Shariah compliance (IFSB, 2017). Some of the notable platforms are summarised as follows:

1. Beehive, a loan-based platform in the UAE, applies a dual approach: it offers both conventional and Shariah-compliant lending options. The Islamic option is described in a detailed manner over its website (IFSB, 2017:120).

2. Yomken, a Shariah-friendly platform based in Cairo, follows profit and loss sharing concept and does not impose any interest rate. No investments will be made in projects associated with industries that are prohibited in Islam, such as alcohol, drug, pork (Taha and Macias, 2014: 118).

International Journal of Management and Applied Research, 2018, Vol. 5, No. 2 
3. Liwwa, a loan-based crowdfunding platform in Lebanon gives a brief explanation of its business model (based primarily on murabahah) in the FAQ section of its website (IFSB, 2017:120).

4. Ethis Crowd and KapitalBoost, are Islam-oriented crowdfunding platforms operate outside the OIC. Based in Singapore, these two platforms provide financing for SMEs and real estate developers (IFSB, 2017:121).

5. Shekra, one of the oldest equity crowdfunding platforms in Egypt, does not explain how it assures Shariah compliance in its website, but the platform follows profit sharing concept (IFSB, 2017:120).

6. Danadidik, an Indonesian platform for student loans, applies a profit and loss sharing model to calculate the returns for investors; however, the Shariah compliance is uncertain (IFSB, 2017:120).

Islamic crowdfunding could respond to the needs of both Muslim and non-Muslim (Taha and Macias, 2014), who might not have the means and resources to access finance. These individuals or firms may have low credit ratings or perhaps lack of guarantees (Kim and De Moor, 2017), but acquire intangible assets which are difficult to quantify using traditional methods. In this context, Shariah-friendly crowdfunding platforms could fill the gaps in the financial industry by providing a means for the crowd in supoorting each other.

For a financial product to be labelled as Shariah compliant, the underlying contract and instrument used in its structuring must be valid in form, substance, and the implementation of the product must be line with Shariah principles (Abozaid, 2014). Form relates to fulfilling the Sharia basic structural requirements and conditions in contract and contractors, while substance is concerned with the essence and the spirit of the structured product, especially when more than one contract or element is involved in the product. The implication of the structured product substantially means the structured product must not lead to evil or have unfavourable or negative implications.

Take donation-based crowdfunding for instance, the suitable instruments would be Hiba, Qard-Hasan and Murabaha. Hibah is a form of benevolent (tabarru') contract which can be applied in crowdfunding platform, where a donor can transfer asset to a recipient without any consideration (Bank Negara Malaysia, 2016). Murabaha refers to a sale and purchase of an asset where the acquisition cost and the mark-up are disclosed to the purchaser (Bank Negara Malaysia, 2013). Murabaha can be an alternative to riba system which using mark-up price as to attain profit. Qard refers to a contract of lending money by a lender to a borrower where the latter is bound to repay an equivalent replacement amount to the lender (Bank Negara Malaysia, 2018).

Marzban and Asutay (2014) proposed a numbers of Shariah-compliant contracts that can be applied to Islamic crowdfunding, and these are summarised in the Table 1: 
Table 1: Islamic Crowdfunding

\begin{tabular}{lll}
\hline Models & Characteristics & Proposed instruments \\
\hline Donation & $\begin{array}{l}\text { Debt-free funding with no payback; } \\
\text { No tangible returns }\end{array}$ & $\begin{array}{l}\text { Hiba; } \\
\text { Qard-Hasan; } \\
\text { Murabaha }\end{array}$ \\
Reward & $\begin{array}{l}\text { Debt-free funding with no payback; } \\
\text { Token of appreciation }\end{array}$ & Sale \\
Loan & $\begin{array}{l}\text { Fixed periodic returns; } \\
\text { Repayment }\end{array}$ & $\begin{array}{l}\text { Murabaha; } \\
\text { Equity }\end{array}$ \\
& $\begin{array}{l}\text { No guarantee on repayment; } \\
\text { Profit-sharing }\end{array}$ & $\begin{array}{l}\text { Ijarah } \\
\text { Diminishing Musharakah; } \\
\text { Musharakah }\end{array}$ \\
\hline
\end{tabular}

Source: IFSB (2017); Marzban and Asutay (2014); Taha and Macias (2014)

An ijarah refers to- (a) a lease contract that transfers the ownership of a usufruct of an asset to another person for a specified period in exchange for a specified consideration; or (b) a contract for hiring of services of a person for a specified period in exchange for a specified consideration (Bank Negara Malaysia, 2018). Leasing gives the opportunity for business especially small companies to continue operation without incurring a high cost to buy a new machine. It is also a chance to inject capital into the business by securing a project.

Musyarakah refers to a partnership between two or more parties, whereby all parties will share the profit and bear the loss from the partnership. On the other hand, a musyarakah may be entered into by two or more parties on a particular asset or venture which allows one of the partners to gradually acquire the shareholding of the other partner through an agreed redemption method during the tenure of the musyarakah contract. Such arrangement is commonly referred to as musyarakah mutanaqisah (diminishing partnership) (Bank Negara Malaysia, 2018). Musyarakah is widely used in investment based financing where the profit and loss are shared between parties. It gives the advantage to both parties as one gets the capital to operate the business and the other get profit from investment.

\subsection{Blockchain-based Crowdfunding}

Blockchain technology could mitigate the problems faced by crowdfunding and traditional banking. For instance, fundraisers could issue their own shares or perhaps smart contracts guaranteeing that pledge contributions would be returned where funding targets were not met. This allows project initiators and crowdfunding shareholders to securely register their rights at low cost (Zhu and Zhou, 2016).

Blockchain has the following characteristics: secure and indelible, distributed ledger, decentralised data management, transparent and auditable, anti-tampering and antiforgery, efficient, low cost, orchestrated and flexible (Guo and Liang, 2016; Niforos et al., 2017; Zhu and Zho, 2016). Blockchain is a decentralized and distributed ledger technology to ensure data security, transparency, and integrity, which cannot be tampered with or forged, and thus it is deemed to have great potential in the finance industry. Table 2 summarises the differences between traditional banking and how blockchain could resolve the issues in crowdfunding.

International Journal of Management and Applied Research, 2018, Vol. 5, No. 2 
The Application of Blockchain Technology in Crowdfunding: Towards Financial Inclusion via Technology

Table 2: How Blockchain Could Disrupt Traditional Banking and Aids Crowdfunding

\begin{tabular}{|c|c|c|}
\hline & Traditional banking & Blockchain \\
\hline $\begin{array}{l}\text { Efficiency } \\
\text { bottlenecks }\end{array}$ & $\begin{array}{l}\text { Complex clearing process; } \\
\text { Large amount of manual inspection; } \\
\text { Many intermediate links }\end{array}$ & $\begin{array}{l}\text { Distributed ledger; } \\
\text { Automated; } \\
\text { Disintermediation }\end{array}$ \\
\hline $\begin{array}{l}\text { Security of } \\
\text { fund } \\
\text { management }\end{array}$ & $\begin{array}{l}\text { A central trusted party; } \\
\text { Complex equity transaction and } \\
\text { transfer }\end{array}$ & $\begin{array}{l}\text { Point-to-point transmission; } \\
\text { Uniqueness of equity transaction } \\
\text { and transfer }\end{array}$ \\
\hline Cost & High cost & Low cost \\
\hline Transaction lag & $\begin{array}{l}\text { Centralised data management; } \\
\text { Leads and lags }\end{array}$ & $\begin{array}{l}\text { Decentralised data management; } \\
\text { Transactions are time-stamped and } \\
\text { can be verified in near real-time }\end{array}$ \\
\hline Operation risk & $\begin{array}{l}\text { Use of information asymmetric which } \\
\text { often leads to adverse selection and } \\
\text { moral hazards; } \\
\text { Double payment }\end{array}$ & $\begin{array}{l}\text { Use of asymmetric encryption; } \\
\text { Transparent }\end{array}$ \\
\hline
\end{tabular}

The benefits of building a platform on blockchain technology are numerous. To illustrate, a crowdfunding platform may:

1. introduce a blockchain based voting system, allowing the crowd or even shareholders to participate in corporate governance in a cost-effective and yet effective manner (Zhu and Zho, 2016);

2. use blockchain-based smart contract to keep track of all changes in the agreement made between the crowd and project initiator, thereby allowing regulators to identify fraudulent fundraising (Niforos et al., 2017; Zhu and Zho, 2016);

3. develop an identity management system that gives full control to users via blockchain (Niforos et al., 2017), preventing identity theft and money laundering;

4. implement digital currency like bitcoin to avoid intermediary like banks and payment providers (Collins and Baeck, 2015)

5. establish the conditions under which a transaction occurs, helping regulators to observe and regulate the quota of investment and qualification of investors (Niforos et al., 2017; Zhu and Zho, 2016)

There are plenty examples of combining blockchain technology and crowdfunding. Initial Coin Offering (ICO), where start-ups use blockchain protocols and cryptocurrency tokens as a means of crowdfunding their ventures, has become a phenomenon. A number of crowdfunding platforms (e.g. Fundedbyme, StartEngine, WeFunder) have already accepting bitcoin. More notably, crowdfunding platforms such as Swarm and Lighthouse allow companies to create their own coins (cryptocurrency) which can be traded for other virtual currencies (Collins and Baeck, 2015).

International Journal of Management and Applied Research, 2018, Vol. 5, No. 2 
Thus, based on the above analysis, with the maturity and wide use of blockchain technology, a secure, efficient, cost-effective crowdfunding platform can be established based on the blockchain technology.

\subsection{Crowdfunding Platforms in Malaysia}

Since the early 1980s, Malaysians have been involved in community-based crowdfunding projects (Asian Institute of Finance, 2017: 16). One notable example is the collection of public contribution to watch live football match in the days when live television was not easily available (Securities Commission Malaysia, 2014). In 1982, a football fan Peter Teo pitched a crowdfunding campaign to pay for the live telecast of World Cup football matches. After several weeks of collection, the campaign successfully raised a total of RM300, 000, which was sufficient to pay live telecasts of the World Cup (Chua, 2018).

In 2012, crowdfunding platforms using digital technology came to Malaysia. The early adopts are largely donation- and reward-based (Cambridge Judge Business School, 2017) and unregulated before 2015 (Asian Institute of Finance, 2017). Securities Commission Malaysia announced a regulatory framework for crowdfunding in 2015 and peer to pear lending in 2016 respectively.

In 2018, the transaction value in the crowdfunding segment amounts to US\$0.7m in Malaysia (The Statista, 2018). Crowdfunding platforms are regulated under the supervision of Securities Commission Malaysia (SCM). In reference to Securities Commission Malaysia (2018), there are seven crowdfunding operators and six peer to peer financing operators registered with SCM (see Table 3). To date, these platforms raised a total of RM118 million collectively, benefiting over 300 micro, small, and medium enterprises (Securities Commission Malaysia, 2018).

Table 3: List of Market Operators licensed by Securities Commission Malaysia

\begin{tabular}{rlll}
\hline No. & Company & Official website & Platform \\
\hline 1 & Ata Plus Sdn Bhd & http://ata-plus.com/ & Equity Crowdfunding \\
2 & Crowdo Malaysia Sdn Bhd & https://crowdo.com/ & Equity Crowdfunding \\
3 & Eureeca SEA Sdn Bhd & https://eureeca.com/ & Equity Crowdfunding \\
4 & FBM Crowdtech Sdn Bhd & https://www.fundedbyme.com// & Equity Crowdfunding \\
5 & Funnel Technologies Sdn Bhd & N/A & Equity Crowdfunding \\
6 & Pitch Platforms Sdn Bhd & https://www.equity.pitchin.my/ & Equity Crowdfunding \\
7 & Crowdplus Sdn Bhd & https://www.crowdplus.asia/ & Equity Crowdfunding \\
8 & B2B Finpal Sdn Bhd & http://www.b2bfinpal.com/ & Peer-to-Peer Financing \\
9 & Ethis Kapital Sdn Bhd & https://www.nusakapital.com/ & Peer-to-Peer Financing \\
10 & FBM Crowdtech Sdn Bhd & https://www.alixco.com/ & Peer-to-Peer Financing \\
11 & Modalku Ventures Sdn Bhd & https://fundingsocieties.com.my/ Peer-to-Peer Financing \\
12 & Peoplender Sdn Bhd & https://www.fundaztic.com/ & Peer-to-Peer Financing \\
13 & QuicKash Malaysia Sdn Bhd & https://www.quickash.com/ & Peer-to-Peer Financing \\
\hline
\end{tabular}

Source: Securities Commission Malaysia, n.d.

International Journal of Management and Applied Research, 2018, Vol. 5, No. 2 
The development stage of these platforms varied: while majority platforms are functioning (e.g. Ata Plus, Crowdo, Eureeca), one company is still under development (Funnel Technologies), and one company expand its services to relevant categories (Ethis Kapital). In particular, the founder of Ethis Kapital, Umar Munshi, has created a number of Shariah-complaint platforms, ranging from real estate crowdfunding (Ethis Crowd) to donation-based crowdfunding (Global Sadaqah).

The key characteristics of the crowdfunding platforms are summarised as follows:

1. Ata Plus, a blockchain-enhanced licensed equity crowdfunding platform, currently uses blockchain technology for record-keeping purposes and accepts bitcoin as an investment instrument since digital currency is not recognised as legal tender in the country (Noordin, 2018).

2. Crowdo, a crowdfunding platform that is fully licensed by regulators in Malaysia, Singapore, and Indonesia. In early 2018, Crowdo announced a strategic partnership and cooperation with Sentinel Chain, a blockchain-based financial inclusion services marketplace(Riana, 2018).

3. Pitch IN, a reward- and equity-based crowdfunding platform active in Malaysia.

4. Eureeca, a Dubai-based equity Crowdfunding platform, have received licensing from the UK, Malaysia and the Netherlands.

5. FundedByMe, a Stockholm based crowdfunding platform, mostly active in Scandinavia but also operates in Singapore and Malaysia.

6. Crowd Plus, an equity crowdfunding platform which has offices in China, Hong Kong Vietnam, and Malaysia.

Nearly 300 campaigns successfully funded via these 6 platforms (Asian Institute of Finance, 2017: 26), and the amounts raised differ significantly. Asian Institute of Finance (2017: 28-29) reported that the lowest amount is RM6 for a technology project and the highest thus far is RM2,636,900 for a brick and mortar business.

\subsection{Shariah Compliant Blockchain-based Crowdfunding in Malaysia}

By its very nature, blockchain technology does not contradict with Islamic teaching since technology is always deemed permissible in Shariah. The utilisation of technology is what makes it lead to Haram or Halal. A careful examination of the blockchain technology suggests that its form, substance and the implication (Abozaid, 2014) are all aligned with Islamic values where it leads to irrevocability and transparency in business. Thus, Islamic finance industry could benefit greatly from blockchain technology in its efforts to provide services in the true spirit of Shariahcompliance.

Malaysia has set up regulatory sandbox for developing blockchain solutions by partnering with industry and technology providers (Niforos et al., 2017: 41). In November 2017, Securities Commission Malaysia announced that it will be embarking on a blockchain pilot project for Over The Counter (OTC) markets (Fong, 2017b). Neuroware, a Malaysia-based blockchain service provider, is the sole technical vendor behind this pilot project. This pilot project is done through the aFFINity Innovation lab, which is an initiative facilitated by the Securities Commission Malaysia to catalyse greater interest towards the development of emerging technology-driven innovations in

International Journal of Management and Applied Research, 2018, Vol. 5, No. 2 
financial services (Fong, 2017a). In February 2018, Neuroware announced that the company is now taking part of government tenders (Neuroware, 2018); in June 2018, the Malaysian government signed a Memorandum of Understanding with a South Korean blockchain lab IncuBlock to develop blockchain platform permissible under Islamic law (Zuckerman, 2018). These recent announcements imply a favourable attitude displayed the Malaysian government towards the blockchain technology.

Based on the above reports, it can be seen that the Malaysia government is open to new developments in financial technology. This finding is consistent with earlier studies which concluded that the Malaysian government and its financial regulator, Securities Commission, have positive attitudes towards financial technology. For example, World Bank (2017) found that the Malaysia government leverage technology to provide financial services to serve low-income households using new instruments and innovative solutions (e.g. agent banking, mobile banking).

\section{Discussion}

The idea of integrating blockchain technology to crowdfunding platform is highly possible to be implemented in Malaysia as it in progress. Malaysia provides a very good blueprint for regulator to engage with the industry, practitioners, experts, potential funders and fund-raiser (Cambridge Judge Business School, 2017). In addition to that, the on-going blockchain pilot project of Securities Commission Malaysia has been a significant milestone on the road of implementation of blockchain technology in the finance sector.

This paper proposes crowdfunding structure that mcombines both Shariah principles and blockchain technology to be implemented in the industry (see Figure 2).

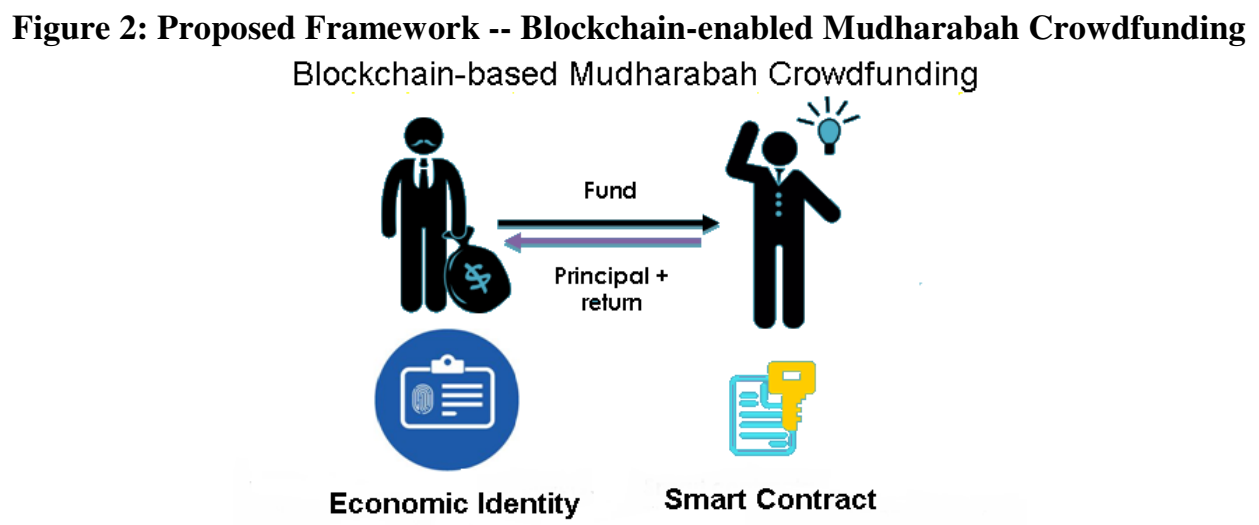

Mudharabah is one of the most popular contracts used in Islamic finance transactions. In a Mudharabah contract, profits and loss are shared according to the profit-sharing ratio. The issuer as the Mudhaarib will pledge the issuance of funds through a crowdfunding platform. The application as Mudhaarib is through blockchain technology; i.e. Economic Identity which provides digital identity to individuals with enhanced privacy, so that identity is restricted to devices as well as other individuals with access. Additionally, Smart Contracts could be used for transaction verification 


\section{The Application of Blockchain Technology in Crowdfunding: Towards Financial Inclusion via Technology}

andstorage purposes, eliminating the need for third-parties. The Mudhaarib discloses all the information with regard to their projects, including the percentage of actual profits divided between them in case of getting return. The crowd, or potential investors, then review the proposal and invest if they consider the project is worthy. Since profits depend on the performance of the venture, both entrepreneur and investor need to allocate resources (both financial and non-financial) efficiently. Mudharabah crowdfunding is thus a symbiotic relationship whereby both parties leverage on the competence of the other.

However, even in this conducive framework, this paper has identified a few challenges that could limit the blockchain technology to be harnessed to its fullest potential in crowdfunding platform. These include:

i. $52 \%$ of the world's population still do not have access to the Internet and one billion people worldwide lack the digital literacy and skills necessary to fully take advantage of ICTs (International Telecommunications Union, 2017). The cost of Internet access is high in developing and underdeveloped economies. As Demirgüç-Kunt et al. (2018) pointed out, mobile phones and internet cannot drive financial inclusion in the absence of necessary infrastructure, namely reliable electricity and mobile networks.

ii. The disadvantaged groups may lack the necessary know-how to attract funding. In equity-based crowrdfunding platforms, prospective entrepreneurs must demonstrate that their ideas are viable in order to attract investments. There is also lack of training and education to equip the disadvantaged groups with necessary skill sets in business administration and information technology.

iii. The crowd size for equity-based crowdfunding is still quite small in Malaysia. This can be attributed to the low public awareness and limited investor pool at the current stage, and they have yet to reach the desired level of maturity (Asian Institute of Finance, 2017).

iv. The current guidelines on equity-based crowdfunding stipulate a cap of RM5,000 per project owner and RM50,000 a year for total crowdfunding investment. Retail investors will need to self-declare that they are willing to take the associated risk if they wish to invest beyond the safety threshold. Such additional step and paperwork may hinder the growth of crowdfunding (Asian Institute of Finance, 2017).

v. Blockchain technology is still at its infancy stage in Malaysia, and thus it takes time to reach a critical mass of the ecosystem participants and to realise full network benefits (Niforos et al., 2017).

vi. The industry needs time to adopt blockchain technology. Executives need to rethink their business model and tested its viability before making any strategic move. To make smart contracts viable, lawyers and regulators will need to develop an in-depth understanding in blockchain (Iansiti and Lakhani, 2017). Their adoption will require major regulatory, economic and social change.

vii. There is an absence of one common set of standards that can ensure the interoperability of systems across industry and supply chains (Niforos et al.,

International Journal of Management and Applied Research, 2018, Vol. 5, No. 2 
2017: 49). Gaining institutional agreement on standards and processes involve coordinating the activity of many different actors (Iansiti and Lakhani, 2017).

To sum up, blockchain-based crowdfunding has a huge potential to be a viable platform to promote financial inclusion. It could make financial services become accessible for all, bridging the gaps between the rich and poor, urban and rural, men and women. Blockchain-based crowdfunding may improve financial inclusion to another level when its mechanism involves the crowd in a sustainable manner. Shariah principles, on the other hand, provide guidelines to build and develop a socially responsible blockchain-based crowdfunding. Taking these together, blockchain-based crowdfunding that is Shariah-compliant could benefit the society as a whole.

\section{Lessons from Malaysia's Experience}

There are several lessons can be drawn from the Malaysia's experience in crowdfunding that could be useful for other countries, especially for countries wish to leverage financial technology to provide financial services to those who face financial constraints.

1. Engaged, open, and proactive regulator: The Malaysian government is one of the first countries in Southeast Asia to introduce crowdfunding regulation. There are regulatory measures of varying scope to safeguard the interests of investors, in addition to ongoing efforts to invite open dialogues with the private sector. Nonetheless, as Asian Institute of Finance (2017: 6) points out, the current regulatory framework requires a periodic recalibration as crowdfunding evolves and market grows.

2. Build awareness: Campaigns, roadshows, and conferences to create awareness of crowdfunding and blockchain are necessary in empowering the financially disadvantaged groups. The mainstream media is also important in showing the benefits of crowdfunding (Asian Institute of Finance, 2017) and blockchain. Media coverage of success stories of crowdfunding and progress on regulatory framework has been useful to attract attentions of the public.

3. Encourage financial innovation: Securities Commission Malaysia and Bank Negara Malaysia have been supportive towards the development of financial technology. Malaysia has adopted regulatory sandbox in October 2016, enabling the experimentation of fintech solution in a live environment, subject to appropriate safeguards and regulatory requirements (Cambridge Judge Business School, 2017; Niforos etal 2017; World Bank, 2017).

4. Education and training: World Bank (2017: 59) reported that the Malaysia government proactively educate the population in improving their financial literacy and encouraging them to adopt new technologies. In the digital age, however, comprehensive training sessions should be provided to aspiring entrepreneurs so that they could improve their marketing and pitching skills to attract investments (Asian Institute of Finance, 2017) using digital technology like video or social media.

International Journal of Management and Applied Research, 2018, Vol. 5, No. 2 
5. Engage with private sectors: Active and constructive dialogue between the regulator and the private sector has been critical in promoting financial inclusion (Cambridge Judge Business School, 2017; World Bank, 2017). Leveraging on resources and inputs from the private sector is crucial in widening financial access to those in need of financial help. Additionally, outreach initiatives with other industry players such as business angel and investment network could enlarge the investor pool in crowdfunding platforms (Asian Institute of Finance, 2017).

6. Shariah-compliant crowdfunding: With Malaysia being an Islamic financial center, its regulatory framework is expected to drive the development of Islamic crowdfunding in the Muslim countries. To date, the number of Shariah-compliant crowdfunding platforms in Malaysia is quite limited. The application of blockchain technology to crowdfunding presents a new chapter in fundraising, financial inclusion, and perhaps Islamic banking. The consensus-based and transactional nature of blockchain (Niforos et al., 2017: 12) could reduce administrative and legal complexities of crowdfunding.

\section{Conclusion}

Crowdfunding is a practice of funding a project or venture by raising small amounts of money from a large number of people via the internet. It can be seen as an alternative to the existing financial services targeted at many different audiences, ranging from aspiring entrepreneur to investor, from the needy to philanthropist. Crowdfunding has the potential to attain financial inclusion. Blockchain technology could bring crowdfunding to another level because it not only helps in enhancing data security but also efficiency and affordability.

It might be too early for jubilation, but there are good reasons to be confident and hopeful about the application of blockchain on crowdfunding and the future of Shariah-compliant crowdfunding platforms in Malaysia. Not least of these is the fact that the regulator has been supportive towards the emerging financial technology.

This paper provides a basis for further work in Islamic crowdfunding and how blockchain might improve crowdfunding platforms. This paper provides background by defining Islamic crowdfunding, providing an overview of its forms and substance, describing the most recent technological trends in crowdfunding, highlighting benefits of integrating blockchain to crowdfunding, and summarising the key barriers to blockchain-enabled Islamic crowdfunfing platforms in Malaysia. Follow-up work could focus specifically on the competitive advantage of blockchain-based Islamic crowdfunding platforms, and how it varies in different economic and legal contexts.

\section{References}

1. Abozaid, A. (2014), Reforming the methodology of product development in Islamic finance, Germany: Lap Lambert Academic Publishing.

International Journal of Management and Applied Research, 2018, Vol. 5, No. 2 
2. Asian Institute of Finance (2017), Crowdfunding Malaysia's Sharing Economy: Alternative Financing For Micro, Small, and Medium Enterprises, Kuala Lumpur: Asian Institute of Finance.

3. Bank Negara Malaysia (2016), Hibah, 3 August, BNM/RH/PD 028-5

4. Bank Negara Malaysia (2018), Ijarah, 29 June, BNM/RH/PD 028-2

5. Bank Negara Malaysia (2013), Murabahah, 23 December, BNM/RH/STD 028-4 I

6. Bank Negara Malaysia (2015), Musyarakah, 20 April, BNM/RH/STD 028-7

7. Cambridge Judge Business School (2017), Crowdfunding in East Africa:

Regulation and Policy for Market Development, available from:

https://www.jbs.cam.ac.uk/fileadmin/user_upload/research/centres/alternativefinance/downloads/2017-05-eastafrica-crowdfunding-report.pdf [accessed on 1 Aug 2018].

8. Chua, J. (2018), "Did You Know That Malaysians Once Sponsored RTM To Air The 1982 World Cup?, Rojak Daily, available from: http://www.rojakdaily.com/entertainment/article/5133/did-you-know-thatmalaysians-once-sponsored-rtm-to-air-the-1982-world-cup [accessed on 1 Aug 2018].

9. Collins, L. and Baeck, P. (2015), Cryptocurrencies could bring cost-savings to crowdfunding and make it easier to hold small stakes in companies, UK: NESTA, available from: https://www.nesta.org.uk/blog/crowdfunding-and-cryptocurrencies/ [accessed on 11 Aug 2018].

10. Demirgüç-Kunt, A. et al. (2018), The Global Findex Database 2017: Measuring Financial Inclusion and Fintech Revolution, International Bank for Reconstruction and Development, Washington, DC: World Bank.

11. Fong, V. (2017a), "Behind The Scenes: Securities Commission Malaysia's Blockchain Project", Fintech News Singapore, available from: http://fintechnews.sg/15270/blockchain/securities-commission-malaysiablockchain-neuroware/ [accessed on 1 Aug 2018].

12. Fong, V. (2017b), "Securities Commission Malaysia Embarks on Blockchain Pilot Project", Fintech News Singapore, available from:

http://fintechnews.sg/13963/malaysia/securities-commission-malaysia-embarks-onblockchain-pilot-project/ [accessed on 1 Aug 2018].

13. Guo, Y. and Liang, C. (2016), "Blockchain application and outlook in the banking industry", Financial Innovation, Vol. 2, No. 1, pp. 24.

https://doi.org/10.1186/s40854-016-0034-9

14. Iansiti, M. and Lakhani, K. R. (2017), "The Truth About Blockchain", Harvard Business Review, Vol. 95, No. 1, pp. 118-127.

15. Islamic Financial Services Board (IFSB) (2017), Islamic Financial Services Industry Stability Report 2017, Kuala Lumpur, Malaysia: IFSB.

16. International Telecommunications Union (ITU) (2017), Fast Forward Progress: Leveraging Tech to Achieve the Global Goals, ITU, Geneva, Switzerland: ITU.

International Journal of Management and Applied Research, 2018, Vol. 5, No. 2 
17. Jenik, I., Lyman T., and Nava, A. (2017), Crowdfunding and financial inclusion, The Consultative Group to Assist the Poor (CGAP), available from: https://www.cgap.org/sites/default/files/Working-Paper-Crowdfunding-andFinancial-Inclusion-Mar-2017.pdf [accessed on 11 Aug 2018].

18. Kim, H, and Moor, L. (2017), "The Case of Crowdfunding in Financial Inclusion: A Survey", Strategic Change, Vol. 26, No. 2, pp. 193-212. https://doi.org/10.1002/jsc. 2120

19. Kirby, E., and Worner, S. (2014), Crowd-funding: An Infant Industry Growing Fast, Madrid, Spain: International Organization of Securities Commissions (IOSCO).

20. Marzban, S. and Asutay, M. (2014), "Shariah-compliant Crowd Funding: An Efficient Framework for Entrepreneurship Development in Islamic Countries", Conference Paper presented in Harvard Islamic Finance Forum, April 2014, Boston, United States America, https://doi.org/10.13140/RG.2.1.2696.1760.

21. Neuroware (2018), Tender Support for Blockchain Technology in Malaysia, available from: http://neuroware.io/blog/tender-support-for-blockchain-technologyin-malaysia/ [accessed on 11 Aug 2018].

22. Niforos, M.; Ramachandran, V.; Rehermann, T. (2017), Block Chain : Opportunities for Private Enterprises in Emerging Market. Washington, D.C.: International Finance Corporation, available from: https://openknowledge.worldbank.org/handle/10986/28962 [accessed on 1 Aug 2018].

23. Noordin, K. A. (2018), "Profile: Putting her faith in equity crowdfunding", The Edge Market, available from: http://www.theedgemarkets.com/article/profileputting-her-faith-equity-crowdfunding [accessed on 11 Aug 2018].

24. Ouma, S.A., Odongo, T.M. and Were, M. (2017). "Mobile financial services and financial inclusion: Is it a boon for savings mobilization?", Review of Development Finance, Vol. 7, No. 1, pp.29-35. https://doi.org/10.1016/j.rdf.2017.01.001

25. Pew Research Center (2011), The Future of the Global Muslim Population, available from: http://assets.pewresearch.org/wpcontent/uploads/sites/11/2011/01/FutureGlobalMuslimPopulation-WebPDFFeb10.pdf [accessed on 1 Aug 2018].

26. Riana, A. (2018), "InfoCorp announces Strategic Cooperation with Crowdo-the First Financial Service Provider to join Sentinel Chain in providing P2P loan services", Medium, available from: https://medium.com/sentinelchain/infocorpand-crowdo-announces-strategic-partnership-for-sentinel-chain-407469424cbf [accessed on 11 Aug 2018].

27. Securities Commission Malaysia (n.d.), List of Registered Market Operators, available from: https://www.sc.com.my/digital/list_rmo/ [accessed on 1 Aug 2018].

28. Securities Commission Malaysia (2014), Annual Report: Part 1 Growing Our Market, available from: https://www.sc.com.my/wpcontent/uploads/eng/html/resources/annual/ar2014_eng/part1.pdf [accessed on 1 Aug 2018].

International Journal of Management and Applied Research, 2018, Vol. 5, No. 2 
29. Securities Commission Malaysia (2018), SC Invites Applications for Registration as Equity Crowdfunding and Peer-to-Peer Financing Operators, available from: https://www.sc.com.my/post_archive/sc-invites-applications-for-registration-asequity-crowdfunding-and-peer-to-peer-financing-operators/ [accessed on 1 Aug 2018].

30. Taha T. and Macias I. (2014), "Crowdfunding and Islamic Finance: A Good Match?”, In: Atbani F.M., Trullols C. (eds) Social Impact Finance. London: Palgrave Macmillan, https://doi.org/10.1057/9781137372697_10

31. Thas Thaker, M. A. M.; Thas Thaker, H. M. and Pitchay, A. A. (2018), "Modeling crowdfunders' behavioral intention to adopt the crowdfunding-waqf model (CWM) in Malaysia: The theory of the technology acceptance model", International Journal of Islamic and Middle Eastern Finance and Management, Vol. 11, No. 2, pp. 231-249, https://doi.org/10.1108/ IMEFM-06-2017-0157

32. The Statistics Portal. (2018). Crowdfunding Malaysia, available from: https://www.statista.com/outlook/335/122/crowdfunding/malaysia\#market-arpu [accessed on 1 Aug 2018].

33. World Bank, (2013), Crowdfunding's Potential for the Developing World, Washington, DC: World Bank.

https://openknowledge.worldbank.org/handle/10986/17626

34. World Bank (2017), Financial Inclusion in Malaysia: Distilling Lessons for Other Countries. Washington, DC: World Bank. https://openknowledge.worldbank.org/handle/10986/27543

35. World Bank (2018), Financial Inclusion Overview, available from: http://www.worldbank.org/en/topic/financialinclusion/overview [accessed on 1 Aug 2018].

36. Zhu, Z., and Zhou, Z. Z. (2016), "Analysis and outlook of applications of blockchain technology to equity crowdfunding in China", Financial Innovation, Vol. 2, No. 1, pp. 29. https://doi.org/10.1186/s40854-016-0044-7

37. Zuckerman, M. J. (2016), "Malaysian Gov't Committee Partners With Korean Lab to Develop Sharia-Compliant Blockchain", Cointelegraph, available from: https://cointelegraph.com/news/malaysian-gov-t-committee-partners-with-koreanlab-to-develop-sharia-compliant-blockchain [accessed on 1 Aug 2018].

International Journal of Management and Applied Research, 2018, Vol. 5, No. 2 